\title{
Book Reviews, Part 2
}

\section{Ethics and Pastoral Ministry}

\author{
Bonhoeffer, D. (Plant, S. \& Burrowes-Cromwell, T., Eds.) (2013) Letters to London: \\ Bonhoeffer's previously unpublished correspondence with Ernst Cromwell, 1935-1936. \\ London: SPCK.
}

I vividly remember sitting in a tutorial at the end of my first term at University and hearing the news that one Karl Barth had just died. It was December 1968, and I hardly even knew who the man was! Over the next few months, I gradually became acquainted with the three Bs: Bultmann the demythologizer, Barth the restorer and Bonhoeffer the martyr. Unsurprisingly, as a pietistic and naive 19 year old, I was captivated by Dietrich Bonhoeffer. Here was a man whose faith cost him everything, but more, a man who knew how to stand up in the public square without compromise, even if I didn't necessarily agree with everything that he did. If only I could have been as bold and as outspoken as he.

Several of his writings have been formative for me: The Cost of Discipleship, Christology, Life Together and Letters and Papers from Prison stand out. Over the summer, I've been supervising a Spirituality essay on Life Together, a text born out of the need to train ordinands for radical discipleship in the German Church crisis. Imagine my wonder, then, to hear that there had been one of those remarkable discoveries: the romance of the longhidden manuscript found, not by an assiduous researcher but by the son of the recipient of these letters, during a house refurbishment.

Ernst Cromwell was a confirmand of the young Bonhoeffer during his ministry in England, at the German Evangelical Church in Sydenham. The two formed a strong pastoral bond which included a notable hill-walking trip to Scotland in March 1935. Bonhoeffer returned to Germany in April 1935; the correspondence with Ernst begins just before his return home and ends about a year later. There are twelve letters of varying length, reproduced in full in English translation.

This is a short book, consisting of the letters (twenty-nine pages), an account of the friendship in historical and political context, an interview with the 91 year old Ernst (now Ernest) Cromwell, and a twenty-three page afterword by Cromwell's daughter-in-law, itself a stimulating and challenging essay on public discipleship.

I was fascinated by the insight the book gives into the struggles of a leader to live out his Christian faith in disturbed and disturbing times. I was moved almost to tears to discover what I should have known sooner, that Bonhoeffer paid visits during his stay to Kelham (my father's theological college) and Mirfield (my college) as part of his preparation for setting up the Confessing Church seminary at Finkenwalde. So Life Together is modelled in part on the same formational principles under which I was trained. My father's Rule of Life (the 
Principles of the Society of the Sacred Mission), which I still read as a practical treasury of Benedictine wisdom, makes even more sense now.

As in any such collection of letters, there is a mix of trivia ('I had to walk to the airport'), good pastoral advice ('The confession of one's sins... belongs... not in the marketplace, but rather in the privacy of your own room'), spirituality and theology ('the most important thing is to hold fast to the truth and not let anything else influence you').

As you can tell, this book excited me, because it felt like part of my story too. It's a specialist read, but an easy one. I commend it as a good example of how spiritual direction often works best, obliquely, lightly but profoundly, welling up naturally from the faith and experience of the prayerful and caring spiritual guide

Adrian Chatfield

Ridley Hall, Cambridge

\section{Earey, M. (2013). Beyond Common Worship: Anglican Identity and Liturgical Diversity. London: SCM.}

I got Mark's latest offering as soon as it came out, and couldn't put it down, but then I agree with his primary thesis. I wrote on Facebook that 'Earey's new book is proving very stimulating: "How can a Church survive which says its liturgy is vitally important to its very sense of identity, yet has key liturgical resources which are proving to be baffling, difficult and restrictive, and - as we shall begin to see in the next chapter - increasingly ignored?" (Loc. 547 - Kindle Edition). I was slightly naughty to choose that quotation, and predictably there followed a slightly tetchy exchange between authors and champions of Common Worship and those who, while valuing CW, share some of Mark's concerns. The key concern is that ' $\mathrm{CW}$, despite its flexibility and variety, is still working on an older model, a model based on central control, a model now creaking at the edges' (512).

Chapter Two presents a number of solutions, mostly around simplified and repositioned rubrics, all of which work on the assumption that the model of central control is still workable. As some of my respondents made clear, cultural divergence, the rise of orality, and a 'couldn't care less' attitude make this problematic. For those who value the tradition but keep bumping up against the boundaries, CW is a 'flexible liturgy that feels controlling' (my italics). He demolishes the myth that it is only certain evangelicals who are finding the boundaries tiresome. He notes that 'creatives', 'radicals/progressives', New Wine churches and Fresh Expressions all find the controlling flexibility frustrating, along with some AngloCatholics and conservative evangelicals.

Then he tries a different tack, that of local episcopally-managed variance. However, as he points out, Mission-Shaped Church and subsequent legislation has missed the opportunity to add liturgical flexibility to the structural flexibility afforded by Bishops' Mission Orders. 
The solution, as Earey sees it, is to move from a bounded-set approach to liturgy towards a centred-set approach, in which even the centre may have 'fuzzy' elements. 'This allows us to recognize that being Anglican can be about "becoming," growing, maturing, holding to Anglican values, or developing an Anglican approach or an Anglican tradition, rather than just ticking or crossing a series of boxes which determine whether we are in or out' (1208). This approach depends on identifying a set of key Anglican principles which convey the overall ethos of Anglican worship, descriptive rather than prescriptive. David Stancliffe uses the word 'style' here, but for me, 'ethos' is more substantial and less preference-based.

The latter part of the book works out the practical implications of all this, from the revision of canons through 'making the rules worshipper-focused rather than institution-focused' to a newly envisioned Liturgical Commission with a very different brief. He concludes that this is a game-changer, and I agree. Will it happen? Yes, but it will probably take far too long. Better for our bishops and synods to grasp this nettle now than to allow reformation to take place through a process of benign neglect. Very well done, Mark, for turning up the temperature of this debate.

Adrian Chatfield

Ridley Hall, Cambridge

\section{Heywood, D. (2013). Transforming Preaching - the sermon as a channel for God's word. London: SPCK.}

It is a joy to read, and commend, a book where the blurb so accurately describes the content: 'Rooted in a clear understanding of the indispensable authority of God's word, Transforming Preaching provides a wealth of practical wisdom and advice for anyone approaching the task of preaching for the first time. It also serves as a useful refresher for all who want to increase the effectiveness of their preaching ministry.' It is warmly commended by two of the finest teachers/writers on this topic in recent years - David Day, formerly Principal of St John's College, Durham, and Stephen Wright, formerly Director of the College of Preachers.

The author is Director of Pastoral Studies at Ripon College Cuddesdon, and pursued doctoral studies in the way Christians learn and grow in their faith. Your reviewer has taught preaching for many years for the College of Preachers, and for one year helping out at Wycliffe Hall Oxford.

Heywood argues that preaching is an agent of change - it should play a key role in transforming the thinking and the life of individuals and congregations. It is clearly written, thoughtful, continually thought-provoking, and contains many useful practical examples and exercises. There is excellent guidance for further reading after each section, but there is no index. 
Part One is Why preach? Attention is given to the contexts of contemporary culture and the Church's life and worship - the relation to teaching, pastoral care, leadership and evangelism. Important things are said about emotional tone, dynamic and the impact of the live spoken word.

Part Two is The sermon as a learning event. Three questions are addressed - how do people listen?, how do we learn? and how do we change attitudes and behaviour? The section is full of important material presented in a thoughtful and sensitive way.

Part Three is much the longest section A step-by-step guide to sermon preparation. Few words are wasted, and the reader must beware the temptation to hurry along. The topics include getting the (key) message, elements of structure (and varieties), visual images, language that engages the audience, introductions and conclusions that achieve attention and response. The whole section achieves very effectively what it says in its title.

Part Four is entitled Involving the congregation and sub-titled interactive preaching. It is only fifteen pages, and seems not carry the authority of research and experience that marks the rest of the book. It is worth reading carefully, engaging with and discussing in a group. But it bristles with questions and problems. The practice, for example, of using a roving microphone round a congregation of $50+$ to elicit questions, illustration and testimony can be illuminating. But how can it truly be called involving the congregation? when usually, at most, only five to ten people will contribute, and they are likely to be either the confident and articulate or those with a particular axe to grind. Similarly, asking people to discuss in small groups can be excellent for some, but a major problem for others. Now the fact is that in the earlier parts of the book, the author has been at pains to show in skilful ways, how, at almost every stage of a good sermon, the speaker will be involving the congregation in numerous ways. 'Losing control' even for a minute or so in a mini-interview may not seem a big deal to the preacher, but may be wincingly painful or excruciatingly embarrassing to others.

But altogether - highly recommended.

Gordon Kuhrt

Haddenham, Bucks

Kirchhoffer, D., Horner, R. \& McArdle, P. (Eds.) (2013). Being Human: Groundwork for a Theological Anthropology for the $21^{\text {st }}$ Century. Preston, Vic: Mosaic Press.

What does it mean to be human? This is the question posed by David Kirchhoffer, Robyn Horner and Patrick McArdle in their welcome book that engages with theological anthropology. The authors set out to build and expand upon the teaching of the Roman Catholic Church, and especially Gaudium et Spes. So this work is firmly centred on the issue of 'human dignity' and the notion of the 'common good' - two topics that have worked their 
way into the repertoire of many ethicists and contemporary ecclesiologists. Taking the themes of Gaudium et Spes as a starting point, the authors wrestle with developments in theology and philosophy over the last fifty years, and explores the 'new knowledge' that now shapes our understanding of what it means to be human.

The book is divided into five parts. The first deals with the interpretive lenses needed for reading theological anthropology today. The second addresses the challenges of anthropocentrism, alterity, incarnation and post-modernity - in some ways, the most interesting and demanding section of the book. The third section tackles the concepts of moral conscience, responsibility, evil and guilt. The fourth turns to explore atheism, fundamentalism and science and pluralism. The fifth and final section considers the relationship between the individual, the community and the (post-?) modern secular state.

Readers will find much here to engage with, and the authors - all from the Australian Catholic University - have produced a very fine book that surveys the challenges to Gaudium et Spes that have emerged over the last sixty years. Readers who are not Roman Catholics will gain much from the text, even though the theological presuppositions that undergird the book may not be shared, or easily transferrable. One of the continuing and enduring features of Roman Catholic ethics and ecclesiology is to approach contentious issues from the starting point of ecclesial ideology or theological foundationalism, and then move to the concrete. A no less worthy challenge might be to start from the concrete, and question some of the foundations, and the concreteness that might have produced them - albeit long ago; to move, in other words, from experience to interrogate tradition. It is on such issues gender, sexuality and the origins of life, to name but a few - that many denominations now find themselves challenged.

It is interesting that Pope Francis has begun his papacy with a series of initiatives that seem to signal some break with the past: where he lives, what he wears, how he travels and so forth. And as I write this, he has issued an invitation to the wider Roman Catholic Church especially the laity - to be consulted on the teaching and pastoral ministry of the church in relation to issues such as divorce, sexuality and family life. It is early days, to be sure; but perhaps not too early to hope for the kind of change in the life of the church that would see it move from dogma and strict discipline to a ministry of mercy. We shall see.

Meanwhile, the authors of this book have done a more than thorough job of engaging with the besetting issues of our age. And the book shows us that there is every hope that the Roman Catholic Church might help all the voices in the wider church to find the wisdom and the insight to speak with such acuity into our secular, consumerist age. Engaging with contemporary culture - the politics, life, love and human condition of the twenty-first century - is arguably the most important front line for the churches today. We need a wisdom to engage with the issues before us; the debates on sexuality and gender, for example, will not go away, no matter who says the debate does not exist. These issues are 
not 'out there' anymore; they are well and truly inside the church, and they shape our ecclesiology too. Can our churches address these issues with theological imagination, integrity and compassion, and find a way forward? Physician, heal thyself.

Martyn Percy

Ripon College, Cuddesdon, Oxford

\section{Lovell, G. \& Richardson, N. G. (2011). Sustaining Preachers and Preaching: A Practical} Guide. London/New York: T\&T Clark International.

In Sustaining Preachers and Preaching, we are offered the carefully considered reflections and wisdom of two experienced Methodist preachers. Lovell is a Methodist minister and consultant in the field of ministry and mission and was awarded a Lambeth Palace DD in 2006. Richardson was Tutor and Principal of Wesley College, Bristol, and also President of the British Methodist Conference in 2003-2004. Although both authors speak from their own Methodist background, preachers (lay and ordained) of all denominations can find helpful guidance, encouragement and challenge in their insights.

Drawing upon their considerable experiences as preachers and teachers of preachers, Lovell and Richardson attempt to address what they call a 'crisis in contemporary preaching.' Preachers, they say, are unsure of what they are doing and what they are supposed to be saying, and they are unconvinced of the worth of preaching. Preaching and preachers need sustaining more than ever due to: first the pressure of preaching in an ever-changing world (characterised by augmented individualism, indifference to the Christian faith, and relativism, and the increasing possibility for human self-destruction through nuclear threats and climate change); and second the unhealthy isolation of most preachers. These problems can be addressed through encouraging preachers to develop and strengthen support networks, and evaluate their practice of preaching in an ever-changing world. Indeed, so the authors argue, these problems must be addressed since the renewal of preaching and the renewal of the Church go hand-in-hand.

The book is divided into five parts, containing a total of thirteen chapters. Part One introduces many of the themes which are addressed later in the book but focuses particularly on outlining the role of preaching and the preacher. Part Two focuses on the life, vocation and relationships of the preacher, whilst Part Three is concerned with the sermon itself and its construction. Part Four outlines some of the sources of support available to preachers and contains a detailed case study of the authors' own local development programme for preachers. Finally, returning to many of the themes introduced in the opening section of the book, Part Five is concerned with sustaining preachers in a fast changing world.

Helpfully, each chapter is clearly titled making it possible for the busy preacher to head straight to the section which draws their attention. Individual chapters could, on the whole, 
be understood if read alone but (as the many cross-references to other chapters indicates) the book gives the impression of being intended to be read as a whole. Those who find themselves feeling isolated in their preaching ministry or who feel their preaching is becoming stale might find Chapter Nine on 'Sustaining Personal and Interpersonal Support' particularly helpful.

The language used by the authors is pleasingly accessible but the style can make the book a little laborious to read at points. In particular, less repetition and more succinctness would have been appreciated - especially considering the acknowledgement by the authors that preachers are generally very busy people with little time to spare! The inclusion of a number of diagrams (of 'the preaching circle', for example) is a welcome addition.

The subtitle of the book markets it as 'A Practical Guide'. However, it should be noted that this is a practical guide to sustaining preachers and preaching, not simply a 'how to' of sermon writing: if that is what the reader is seeking there are more appropriate resources available.

Anna Leyden

Liverpool

\section{Nazir-Ali, M. (2012). Triple Jeopardy for the West. London: Bloomsbury.}

The threat is clear from the title: we are assailed on every side, by 'aggressive secularism, radical Islamism and multiculturalism'. The question is whether they can be lumped together as a trinitarian axis of evil. Indeed, the question ought to be asked whether a paranoid perspective on threats to Western society or culture is proper, or even biblical.

Don't get me wrong. I'm not a liberal when it comes to spiritual warfare, nor a moderate when it comes to understanding the depths of social and political depravity to which our fallen nature can drag us individually and corporately. It's just that I'm not sure whether living life as if under a cloud is a helpful metaphor for us.

Predictably, the book frustrated me by being a collection of articles, many of which have been published before, with the 'triple jeopardy' thesis as the conceptual framework. The introduction expands on this, with the conclusion that 'Christians will and should argue for justice because of their beliefs and because of the common good, but it would be foolish and premature to give up on the Christian foundations of the nation which may make the achievement of such justice possible' (xv).

So it is a manifesto for public theology, and the retention, or recovery of the idea of a nation built on Christian foundations that is the positive driver for the collection. Within, the material is so diverse that it is impossible to offer review comment without analyzing each 
piece separately. Part One, on 'Society: The state and the good citizen' ranges widely over debates on multiculturalism, happiness, and the decline of Christian influence.

The second section contains four essays on aspects of Islamic fundamentalism, and it is striking that the author - by using the word 'Islamism', suggests strongly that this is not real Islam at all, a view which I and many more competent scholars share. My experience of Islam in Trinidad and Tobago is that its moderation enabled a creative interaction with Christianity and Hinduism until aggressive black Islam began to breed a culture of revolution, of fear and of violence.

I suppose that the third section is held together by its concerns with the advance of ethical liberalism, in discussions on evolution, assisted dying and more generally on bioethics, more newspaper comment than learned article.

The quality and length of the articles is very varied, with chapter five on 'Islamic law, fundamental freedoms and social cohesion' by far the longest. Here of course Nazir-Ali is supremely at home, and as a Christian interpreter of Islam who understands that faith deeply from within, he is outstanding. And his final article, 'Where do we go from here?' is helpful because it gives us the book's manifesto for change. This is, for Christians to re-enter the public sphere, for us all to recognize and promote the Christian foundations of our society, and implicitly, to help the nation to incorporate key Christian principles like that of the family into the fabric of national life not because they are Christian, but because they make sense.

Would I buy this book? Yes, because I share the Bishop's concern with the rise of systems that are both antagonistic to Christianity and morally, logically and philosophically utterly flawed. It will annoy, but it will also stimulate and instruct.

\section{Adrian Chatfield}

Ridley Hall, Cambridge

\section{Pike, M. A. (2013). Mere Education: C.S. Lewis as Teacher for our Time. Cambridge: Lutterworth Press.}

The film Shadowlands depicts C.S. Lewis speaking at the annual conference of the Association of Christian Teachers. However, since ACT was not founded until 1971 and Lewis had died in 1963, such an occurrence seems unlikely! It is nevertheless true that Lewis was a Christian teacher whose approach to education was deeply influenced by his faith and who would probably have been very much at home speaking at a conference of ACT had it been in existence in his lifetime.

In Mere Education, Mark Pike has given us a clear and well-written account of central themes that he finds in Lewis's philosophy of education. He relates these themes to 
developments in western education in these early decades of the twenty-first century. His aim in doing so is 'to help parents, teachers and leaders to set boundaries so that they can protect schools and schooling from the incoming tide of ideological assumptions that threaten to erode and undermine the wholeness and purity of education' (11-12).

The book is in four parts, each sub-divided into three short chapters. The chapter subjects are: character education, Christian education and spiritual education (part one); liberal education, sex education and biblical education (part two); cultural education, citizenship education and democratic education (part three); and teacher education, leadership education and future education (part four). Each chapter concludes with a helpful study guide consisting of twelve tasks and questions for discussion.

Mark Pike (and, from what he says, his wife and children) are clearly lovers of the work of Lewis. The book provides abundant evidence of this and of very thorough research not only in Lewis's own writings but also in those of a number of contemporary writers. The chapters, although relatively short, have an average of over forty footnotes and the bibliography includes over forty books and articles by Lewis and no fewer than two hundred by other writers, of which twenty are from the author's own pen.

This book makes an original and substantial contribution to the already large volume of research on Lewis's life and work. With its focus on Lewis as a teacher, it was surely a book waiting to be written and one wonders why nobody had taken on the task before now. Happily for fans of Lewis and enthusiasts for Christian perspectives on education, Mark Pike has done so and this important book has now appeared, some fifty years after the great man passed away.

Lewis's view of education as interpreted and applied to the contemporary scene by Mark Pike is clearly deeply influenced by the Christian faith. Having said that, it should be noted that the particular approach that this book takes to 'the reclamation of education and schooling' (as the author terms it on page 12) would not be universally endorsed by contemporary Christian educators. It seems quite close to the 'Classical Christian Education' approach which has come to be influential among many Christian home-educators and in some Christian schools. An important inspiration for this approach is an essay by Dorothy $L$ Sayers entitled 'The Lost Tools of Learning'. Sayers was a contemporary of Lewis at Oxford and Mark Pike notes that Lewis corresponded with her and goes on to give some detail of her 'tools' of the trivium (grammar, rhetoric and logic) and quadrivium (arithmetic, geometry, music and astronomy) highly regarded in Ancient Greece and in Medieval Europe (57). Lewis has much to teach us about Christian education but we should be aware that there are other Christian 'teachers for our time' to whom we should also listen. 


\section{Rosman, D. (2011). Evangelicals and Culture. Eugene: Wipf and Stock.}

The first thing to say about this book is that any volume which commences with a Foreword from David Bebbington will be worth reading. And so it proves to be in this study from Doreen Rosman, who has produced a sharply observed study of evangelicalism between 1790 and 1833. The burden of Rosman's work is to challenge the pervasive contemporary criticisms of evangelicals - that they were anti-intellectual, engaged in a kind of cultural philistinism, and were otherwise rather drab ascetics. As Rosman's work shows, this is some way short of the full picture. True, there were indeed evangelicals who shunned worldly exploits as vanity, and resisted almost any current in public culture. Whether that was suspicion of plays, novels or the arts - or more nuanced critiques of socio-political issues evangelicals were often known for swimming against the tide.

Yet as Rosman's work shows, evangelicals were much more engaged with culture than many might suppose. Utilising evidence from letters, memoirs, wills, magazines and periodicals, she shows that evangelicals were heavily involved with literary, aesthetic and cultural pursuits. Indeed, the theological interests of evangelicals - those that drove them to engage with the world so strongly - equipped them no less for a serious engagement with culture. Rosman also shows that evangelicals in this era had far more in common, in terms of taste, with their contemporaries, as is usually acknowledged. Whilst a strong Calvinist tradition tended to operate in a kind of fright-flight-fight vein in relation to the world, many evangelicals engaged both constructively and critically with culture. The politically pragmatic Clapham Sect provides some exemplary evidence for this.

Readers will be impressed with the sharp observations and careful scholarship of Rosman. Her work is able to take account of faith and fashion, family life, fun and leisure, as well as the fine arts and the broader intellectual debates of the era. This is a thoughtful and wellcrafted book, which broadens our views of evangelicalism. It shows that evangelicals were able to not only negotiate the cultural currents of their era, and surf some waves too - but were also able to read the tides. Her book will make any reader appreciate just how deeply and widely evangelicals thought - and then engaged with culture.

Martyn Percy

Ripon College, Cuddesdon, Oxford

Stanley, B. (2013). The Global Diffusion of Evangelicalism: The Age of Billy Graham and John Stott. Nottingham: IVP.

'Dwell on the past and you will lose an eye; forget the past and you will lose both eyes.'

Often Evangelicals have a nostalgic view of the past, whether it is those of us who believe the Reformation was the high water mark of Christianity or those of us who discovered the worship revival of the 1970s, Evangelicals often enjoy reminiscing of better days. But a Cyclops still has an advantage over the blind so it would seem a wise investment to explore 
the history of a movement that has grown to global status so rapidly over the past half century.

Brian Stanley is the most qualified person I can think of to write the fifth volume in IVP's 'A History of Evangelicalism' series. Rather than attempting a narrative history of the 1940 s to 1990s of evangelicalism, Professor Stanley writes an introduction and then eight thematic essays exploring a broad range of trends.

The first essay explores the evolving relationship between evangelicalism and fundamentalism. The second essay explores how evangelical networks globalised. Stanley focuses on the ministry of Billy Graham, the formation of the World Evangelical Fellowship (now known as the World Evangelical Alliance), the indigenisation process at work in Scripture Union and the worldwide effects of the East African Revival. The third essay highlights the growth of evangelical scholarship once thought an oxymoron due to confusion between Evangelicals and fundamentalists. The development of Tyndale House in Cambridge is shown to have played a vital role.

In his fourth essay Professor Stanley tracks the development of evangelical apologetics and highlights the work of Cornelius Van Till, Edward Carnell, Carl F. Henry, Francis Schaeffer and Alvin Plantinga who in different ways helped Evangelicals to defend the faith in the academies. Yet Stanley demonstrates that non- Evangelicals such as Lesslie Newbigin and more significantly C.S. Lewis offered 'an intellectual armoury of a very different kind from that offered by the sterling efforts of conservative theologians.'

The captivating story of the Lausanne Congress on world evangelisation is told in the fifth essay. The Congress, the brainchild of Billy Graham, and after some coercion joined by John Stott brought together leaders from across the world in 1974. Stanley tells how the American-dominated programme was challenged by Latin American theologians: Rene Padilla (the need to rethink the cultural accommodation of Christianity in the West), Samuel Escobar (the need to engage with social justice in mission) and Orlando Costas (the need for contextualisation). Tribute is paid to John Stott's mediatory skills in helping to include these insights into the final Lausanne statement.

The sixth essay tracks the development of global charismatic and Pentecostal movements. Tracing the rise in healing ministries, John Wimber, the adaptation of worship music, the Toronto Blessing, the impact of Bretherenism on Newfrontiers and the birth of Alpha. Stanley is on the whole positive about the impact, stating: 'The global evangelical family gained much-needed spiritual vitality as a result.'

The seventh essay tackles hermeneutics, gender and sexual ethics. I think it was somewhat unfortunate to lump these issues together. There are very few women mentioned in the entire volume - the history of the global proliferation of evangelicalism is mainly told through white male leaders. When Stanley does get round to engage with women it is in the 
context of a debate around the role of hermeneutics that ends with an exploration of evangelical responses to homosexuality. It was a shame that the role of women in the proliferation of evangelicalism is only cast in the middle of this debate.

The last essay was a sobering one to read. Professor Stanley attempts to summarise the trends he sees at work in the evangelical world today. Stanley revisits the post-evangelical debate of Dave Tomlinson and comments that many conservatives refuse to see a difference between post- Evangelicals and post-conservatives such as Stanley Grenz and N.T. Wright. Stanley seeks to mediate the divide between Postconservative/Open Evangelicals and Conservative Evangelicals. After citing Carson's withering critique of Stanley Grenz's 'Renewing the centre' where Carson concludes that Grenz's work was 'truly outside of the evangelical camp' Brian Stanley states that: 'Grenz, however remained until his death a faithful member of First Baptist Church, Vancouver, under the conservative expository ministry of Bruce Milne... Assessments of the state of evangelicalism can be misleading if they focus exclusively on academic theological arguments and neglect the evidence of spirituality and church life.'

In many ways this book, though skilfully written, is a depressing read. Stanley recognises this in his summation when he states: 'It is part of the vocation of the church historian to remind Christians who may be depressed about the current condition of the church that states of division and uncertainty are the norm rather than the exception in Christian history' (237).

Sadly, I think Brian Stanley is optimistic in his closing sentiment that the battle for the integrity of the gospel in the opening years of the 21st century is being fought not primarily in the lecture rooms of North American seminaries but in the shanty towns, urban slims and villages of Africa, Asia and Latin America.' We praise God for the proliferation of the gospel that is bearing so much fruit among the poor. We rejoice that the centre of gravity of the Church has moved to the global south. But in my limited experience of working with the poor - the gospel that is being spoken about there looks a lot like the Western individualistic virtually-gnostic version that we have exported. The battle for the integrity of the gospel is being fought on social media and in the budget meetings of western publishers and conference organisers where global celebrities are made out of certain preachers who export their cultural assumptions to the rest of the world. We need to allow the spirit of the first Lausanne congress to continue on and allow the global church to be reshaping our understanding of mission and the gospel in the light of scripture. We need continually to fight the imperialism of Western domination in global evangelicalism.

Stanley's well written and researched book will help Evangelicals to avoid the blindness of ahistoricity; perhaps we need a companion volume to help us know what we can learn from Evangelicals in the non English speaking world?

Krish Kandiah

Executive Director: Churches in Mission at the Evangelical Alliance 
Treier, D. J. \& Lauber, D. (Eds.) (2009). Trinitarian Theology for the Church: Scripture, Community, Worship. Grand Rapids: IVP Academic.

This collection of essays is a very welcome addition to the growing literature on the Trinity. The book coming from a group of American Evangelicals is, as the subtitle indicates, divided into three sections, with an introduction by the editors. Part One: Scripture, contains three essays, two of which come from the pen of Kevin Vanhoozer, possibly the most stimulating and original Evangelical theologian writing today. These essays, tackle the basic question that Scripture is to be understood as Triune Discourse. Noting that Evangelicals regularly insist on the supremacy of Scripture and state their belief separately in God as Trinity, Vanhoozer asks why these doctrines are rarely brought together. Accordingly, his purpose is to argue that the ultimate authority for Christian faith, life and thought is the triune God speaking in and through the Scriptures. This principle is in line with his earlier writings on the doctrine of Scripture.

Part Two deals with the Community, subtitled 'The Trinity and Society'. The essay by John Franke looks at the Social Trinity and the Mission of God. Here he explores the significance of relationality as the most fruitful model for understanding the doctrine of the Trinity. This is an area where Evangelicals have perhaps been weak, often preferring to relate Trinitarian theology to the atonement. Mark Husbands criticises the view that the Trinity is the basis of social programmes. The social analogy is advocated for example by Miroslav Volf who claims that this understanding can be traced back to Gregory of Nyssa in the fourth century. Such a view, argues Husbands, is gravely deficient and one-sided. Keith Johnson examines the notion that the Doctrine of the Trinity holds the key to a Christian Theology of Religions, and concludes almost certainly rightly that a proper understanding of the Trinity does not provide the basis for a new understanding of religious diversity. This is but one example of 'stretching' an ancient doctrine to apply to a modern religious situation not envisaged in earlier times.

Part Three deals with Worship and examines Church Practices in relation to the Triune Mission. Gordon Smith offers a stimulating essay which sees the sacraments of Baptism and Eucharist as the embodiment of Trinitarian Faith, an area which is probably not familiar to many evangelicals. Leanne Van Dyk develops the particular view that the Church's Proclamation is properly understood as a Participation in God's Mission, while Philip Butin understands preaching as a Trinitarian Event. Finally John Witvliet asks what we should do with our renewed Trinitarian Enthusiasm. He offers several stimulating ideas for the formation of Trinitarian Piety and imagination through Worship and Catechesis.

Although this book is not aimed at a general readership, it has implications for ministry both ordained and lay. In particular it raises questions about the widespread dearth of preaching on the Doctrine of the Trinity from evangelical pulpits. I can only write as an Anglican, but I've no doubt that the same holds true for other denominations. One hears stories of clergy who try to avoid preaching on Trinity Sunday and when they do, it is often superficial and 
unimaginative. This book might serve as a wake-up call to transfer the resurgence of Trinitarian Theology from the scholar's desk to the pulpit. It is surely now time to open up the riches of this glorious doctrine to the wider church and congregation. I wholeheartedly recommend it.

Howard Bigg

Cambridge

Yates, T. (2013). The Conversion of the Māori: Years of Religious and Social Change, 18141842. Grand Rapids: Eerdmans.

'A whole nation of pagans converted to the faith' was Bishop G.A. Selwyn's assessment of the effect of missionary work in New Zealand in the first half of the Nineteenth century. Timothy Yates' compact monograph seeks to describe and analyse this spiritual and social change amongst the indigenous inhabitants of New Zealand.

This scholarly study by one of Britain's foremost mission historians (and a former chair of the Anvil Editorial Board) is a welcome addition to Eerdmans' Studies in the History of Christian Mission series, a growing resource for the missiologist and mission historian. That said, this is probably a book for those with a specialist interest in missions, in anthropology or in the history of New Zealand rather than for the general reader, though Yates' very readable prose style makes the subject more accessible than might otherwise be the case

After a survey of traditional Māori society Yates uses primary source material from the missionary societies' archives to trace the progress of the three European missions, Anglican (CMS) from 1814, Methodist from 1819 and Roman Catholic (Marist) from 1838. The 1840 Treaty of Waitangi forms a natural terminus ad quem to the account of the European missions in New Zealand.

But Yates does not stop there. In keeping with the current emphasis in missionary history on the missionary contribution of indigenous converts rather than that of the European missionaries the final chapters of the book (10-12) are in many ways the most revealing. In examining the nature of conversion he approvingly quotes Lesslie Newbigin's model of conversion as being a three-fold process (later popularly summarized as 'believing, belonging and behaving'). And building on the seminal work of Raeburn Lange Yates examines the work of the 'indigenous agents' of the mission and notes that numbers of converts rapidly increased once the Gospel was shared with Māoris by other Māoris rather than by Europeans. There is clearly a message here for those engaged in cross-cultural mission in the Twenty-First century!

Yates does not fall into the popular trap of dismissing European missionaries as cultural and religious imperialists. By endorsing Norman Etherington's observation that 'the overwhelming evidence [is] that the agents of conversion were local people not foreign missionaries' he recognizes that in New Zealand they had a specific and limited role. In his 
most memorable phrase Yates seeks to summarize and define this role: 'the missionaries should be given their due as religious and social catalysts (my italics) whose self-denying labors [sic] made an impression on the Māori'. This perceptive summary of the missionary contribution has meaning far beyond the New Zealand context and it is to be hoped that other scholars will seek to use and to test this important new insight in their own explorations of mission case studies from other parts of the world.

John Darch

Diocese of Blackburn 